\title{
Role of mast cells in the pathogenesis of hypersensitivity pneumonitis
}

\author{
P SOLER, S NIOCHE, D VALEYRE, F BASSET, J BENVENISTE, C BURTIN, \\ J P BATTESTI, R GEORGES, A J HANCE
}

From INSERM U82, Faculté Xavier Bichat, Paris; Service de Pneumologie, Hôpital Avicenne, Bobigny; and INSERM U200, Clamart, France

\begin{abstract}
To examine the possibility that mast cells have a central role in the pathogenesis of hypersensitivity pneumonitis, 20 patients with this disease were studied with the aim of seeking evidence for mast cell degranulation. The number of mast cells recovered by bronchoalveolar lavage from patients with hypersensitivity pneumonitis was more than 1000 times greater than those recovered from normal individuals. Furthermore, discontinuation of antigen exposure resulted in an increase in the number of mast cells observed, consistent with the possibility that antigen exposure had induced mast cell degranulation. Cessation of antigen exposure also resulted in a rapid decrease in the number of neutrophils and eosinophils recovered by lavage, followed by an increase in the number of $\mathrm{T}^{+} \mathrm{T}$ lymphocytes present. In each case the time course of the changes was consistent with the possibility that mast cell degranulation had been important in regulating the number of the immune and inflammatory cells present in the lung. Histamine was present in lavage fluid supernatant from patients with hypersensitivity pneumonitis. The amount of histamine present was, however, closely correlated with the number of mast cells present and not with the interval since last antigen exposure. Delay in separating cells from lavage fluid supernatant resulted in an increase in histamine content. These results suggest that the free histamine in lavage fluid resulted from the degranulation of mast cells induced by the lavage procedure as histamine released in vivo has a short half life. We suggest that hypersensitivity pneumonitis results from a "late phase reaction" initiated by antigen induced mast cell degranulation.
\end{abstract}

\section{Introduction}

Hypersensitivity pneumonitis (also called extrinsic allergic alveolitis) is an interstitial lung disease resulting from an immune reaction to inhaled organic or inorganic antigens. ${ }^{1-3}$ Characteristically, patients intermittently exposed to antigen report the onset of dyspnoea and fever four to eight hours after antigen re-exposure. This reaction can be reproduced in all patients under controlled conditions. When patients are removed from contact with the sensitising agent for several days and then challenged by inhalation of the antigen, fever, crackles, pulmonary infiltrates, and a restrictive ventilatory defect develop four to eight hours after exposure. ${ }^{24}$ Patients chronically exposed to the sensitising agent frequently develop intra-

Address for reprint requests: Dr Allan J Hance, INSERM U82, Faculté Xavier Bichat, 16, Rue Henri Huchard, 75018 Paris.

Accepted 16 February 1987 luminal and interstitial fibrotic changes, which may be poorly reversible despite discontinuation of antigen exposure and institution of corticosteroid treatment. ${ }^{4-7}$

Various reports have investigated the pathogenesis of hypersensitivity pneumonitis. The alveolitis of this disease is characterised by normal numbers of alveolar macrophages that often have foamy cytoplasm and large numbers of activated $T$ lymphocytes, which proliferate in response to the sensitising antigen. ${ }^{6-16}$ In unselected patients variably increased numbers of neutrophils, eosinophils, and mast cells are also present, ${ }^{6-16}$ and when patients are challenged with antigen under controlled conditions the rapid but transient appearance of large numbers of neutrophils has been demonstrated. ${ }^{17}$ Increased concentrations of immunoglobulins, including immunoglobulins directed against the sensitising antigen, are also present in the lung. ${ }^{9-18}$

On the basis of these findings it has been suggested that antigen exposure produces a chronic immune 
response that results in the production of precipitating antibodies. After re-exposure to antigen, immune complexes are formed that secondarily recruit other inflammatory cells to the lung (reviewed in ref 19). This "Arthus like" response would explain the appearance of symptoms and clinical signs 4-8 hours after antigen exposure and account for the transient presence of neutrophils after antigen exposure. Various arguments, however, have been raised against this scenario. ${ }^{2320}$ Firstly, increased numbers of antigen specific $\mathrm{T}$ lymphocytes and high titres of immunoglobulins directed against the sensitising antigen may also be found in the lungs of symptomless individuals exposed to antigens known to produce hypersensitivity pneumonitis. ${ }^{10111421}$ Furthermore, immune complexes and vasculitic lesions, hallmarks of an Arthus like reaction, are not found in lung biopsy specimens from most patients with hypersensitivity pneumonitis. ${ }^{5223}$ In addition, serum complement levels are usually normal during symptomatic episodes. ${ }^{2425}$ Thus it is useful to consider alternative hypotheses explaining the pathogenesis of this disorder.

We present here the hypothesis that antigen induced degranulation of mast cells has a central role in the pathogenesis of this disease. To evaluate this hypothesis, we have reviewed the results of bronchoalveolar lavage performed on 20 patients with hypersensitivity pneumonitis in a search for evidence that mast cell degranulation occurs in patients with this disorder.

\section{Methods}

\section{STUDY POPULATIONS}

Hypersensitivity pneumonitis We examined records from all patients diagnosed at Hôpital Avicenne as having hypersensitivity pneumonitis from January 1980 to June 1986 . Patients included in this study met the following criteria: (1) history of exposure to antigens known to produce hypersensitivity pneumonitis within 30 days of the date of evaluation; (2) symptoms, clinical signs, and abnormalities on chest radiographs or results of pulmonary function tests compatible with hypersensitivity pneumonitis, or both, and the absence of signs, symptoms, and findings from pulmonary function testing (when available) compatible with a diagnosis of asthma; (3) no history of corticosteroid administration for at least one year before the onset of the present illness; (4) presence of serum antibodies against the relevant antigen as determined by immunoeletrophoresis or immunodiffusion or both; (5) prompt improvement in symptoms, chest radiographs, or pulmonary function test results when further antigen exposure was prevented or, in some cases, when corticosteroid $(0.5 \mathrm{mg}$ prednisone/kg body weight/day) was administered; $\overrightarrow{\vec{F}}$ (6) the date of last antigen exposure before evaluationknown; (7) availability of bronchoalveolar lavage $\frac{}{0}$ data.

The 20 patients (seven men, 13 women) had a mean age of 48 (SD 13) years. None had used tobacco for at least one year before evaluation, although four ${ }^{\infty}$ patients were former smokers. All patients have a his-. $\vec{\circ}$ tory of chronic exposure to avian antigens, and all $\vec{\omega}$ patients presented with subacute symptoms of cough, $\stackrel{\omega}{\circ}$ dyspnoea, weight loss, or fever, or a combination of these, although some patients had a prior history of relapsing symptoms. Two patients had been treated ${ }^{\mathrm{N}}$ with prednisone $\left(0.5 \mathrm{mg} / \mathrm{kg}\right.$ body weight/day) for ${ }^{\circ}$ eight to 12 days after admission to hospital but before $\mathrm{G}$ bronchoalveolar lavage. Chest radiographs showedo bilateral alveolar and interstitial infiltrates in 18 . patients; two radiographs were interpreted as normal. Pulmonary function tests ${ }^{2627}$ (results of completeco testing were available for 16 patients) gave the following mean (SD) values: total lung capacity $76 \%(\mathrm{SD} \overrightarrow{\overrightarrow{0}}$ $18 \%)$ predicted, vital capacity $71 \%(17 \%)$ predicted, $\mathrm{FEV}_{1} / \mathrm{FVC} 80 \%(3 \%)$, residual volume/total lung capacty $119 \%(32 \%)$ predicted, and diffusing capacity (transfer factor), scaled for height and age, $41 \%$ $(16 \%)$ predicted. $\mathrm{P}_{\mathrm{a}} \mathrm{O}_{2}$ was $8.1 \quad(1.47) \mathrm{kPa} \quad(61$ ) (11) $\mathrm{mm} \mathrm{Hg})\left(\mathrm{FiO}_{2} \mathrm{0} \cdot 21\right)$

Other granulomatous lung diseases Results of $\stackrel{\mathbb{Q}}{2}$ bronchoalveolar lavage performed on non-smoking $\overrightarrow{\vec{O}}$ patients with sarcoidosis and all patients with 3 histiocytosis X from January 1983 to June 1986 were also evaluated. Diagnoses were establised according to previously described criteria. ${ }^{28}$ The 92 patients with sarcoidosis (30 men, 62 women) had an average $\frac{\text { 의 }}{9}$ age of 36 (SD 11) years. Patients with histiocytosis $X$ (seven women, five men) had an average age of 25 (10) years; all 12 patients were smokers at the time of eval-i uation. None of the patients in these two groups was을 receiving corticosteroids.

Normal volunteers Fifteen normal non-smoking vol-음 unteers (five men, 10 women; age 20 (10) years) served $\frac{?}{O}$ as controls. Clinical evaluation showed no prior or present pulmonary abnormalities.

All patients underwent bronchoalveolar lavage as part of a diagnostic evaluation. Patients and normal volunteers gave informed consent before undergoing ${ }_{\sigma}^{\omega}$ lavage.

\section{EVALUATION OF CELLS RECOVERED BY}

BRONCHOALVEOLAR LAVAGE

Bronchoalveolar lavage was performed as previously $\frac{T}{0}$ described. ${ }^{28}$ The total number of cells recovered $/ \mathrm{ml}$ 穴 lavage fluid was determined by counting the cells $\frac{\stackrel{\rho}{\mathbb{P}}}{\mathbb{Q}}$ present in a resuspended aliquot of the original lavage $\unrhd$ fluid. Cytocentrifuge preparations were produced with uncentrifuged lavage fluid and stained with 
May-Grünwald-Giemsa stain; a differential cell count was made by examining at least 1000 cells. The maximum interval between lavage and the preparation of specimens for cytocentrifuging was one hour. Mast cells were identified by the presence of characteristic metachromatic granules. In some patients cells with morphological characteristics of basophils were also present. These cells, which were counted as "mast cells," never represented more than $25 \%$ of the total mast cells. Occasional cells were also present that morphologically resembled mast cells except that they did not contain metachromatic granules. Although these cells could represent degranulated mast cells, for this study they were identified as alveolar macrophages. Lavage fluid was centrifuged $(600 \mathrm{~g}$ for 10 minutes) and supernatant fluid was stored at $-20^{\circ} \mathrm{C}$. Cells were resuspended at a concentration of $10^{6}$ cells $/ \mathrm{ml}$ in RPMI- 1640 medium containing $25 \mathrm{mmol} / 1$ Hepes.

The surface phenotype of lymphocytes recovered by lavage was evaluated by indirect immunofluorescence microscopy as previously described, ${ }^{29}$ anti-CD4 (OKT4 and OKT4A, Ortho Diagnostics, Raritan, New Jersey) and anti-CD8 (IOT 8, Immunotech, Marseille, France) monoclonal antibodies being used.

\section{MEASUREMENT OF HISTAMINE CONTENT IN}

LAVAGE FLUID SUPERNATANTS

To measure histamine content, samples of lavage fluid (available for 10 patients) were thawed and a $10 \mathrm{ml}$ aliquot was lyophilised and dissolved in $1 \mathrm{ml}$ distilled water. A $0.8 \mathrm{ml}$ sample of concentrated lavage fluid was then added to $0.2 \mathrm{ml} 2 \mathrm{~N} \mathrm{HClO}_{4}$, and histamine content was measured by an automated spectrofluorometric technique as previously described. ${ }^{30}$ All samples were assayed in duplicate, and results are expressed as $\mathrm{ng}$ histamine $/ \mathrm{ml}$ of original lavage fluid. For eight of the 10 patients whose lavage fluid was saved two different samples of lavage fluid supernatant were available. In these cases lavage fluid had been resuspended and divided into two aliquots. One aliquot was centrifuged immediately and supernatant fluid removed from the cells within 15 minutes of the lavage procedure. For the remaining lavage fluid the separation of cells and supernatant fluid was performed one hour after lavage.

\section{STATISTICAL METHODS}

Results are expressed as means with standard deviations in parentheses unless otherwise stated. Comparisons between patient groups and normal individuals were made with Student's two tailed $t$ test. Comparisons of the numbers of cells recovered by lavage and histamine content in lavage fluid between subgroups of patients with hypersensitivity pneu- monitis were made with the Mann-Whitney test. Correlations between histamine content in lavage fluid and numbers of mast cells present were determined by linear regression. A $p$ value of $<0.05$ was considered significant.

\section{Results}

NUMBERS AND TYPES OF CELLS RECOVERED BY BRONCHOALVEOLAR LAVAGE FROM PATIENTS WITH HYPERSENSITIVITY PNEUMONITIS Patients with hypersensitivity pneumonitis as a group had larger numbers of lymphocytes, neutrophils, eosinophils, and mast cells in their lavage fluid returns than normal subjects (table $1, \mathrm{p}<0.01$ for each comparison of percentages with those from the controls). Two of the patients with hypersensitivity pneumonitis had been treated with corticosteroids before evaluation. The numbers and types of cells recovered from these patients, however, was similar, to those observed in untreated patients, and exclusion of these two patients did not change the results of the statistical analyses reported here.

Of particular importance for this study was the observation that the number of mast cells recovered $/ \mathrm{ml}$ lavage fluid from patients with hypersensitivity pneumonitis was over 1000 times greater than the number recovered from normal individuals. Furthermore, the number of mast cells recovered from patients with hypersensitivity pneumonitis was significantly greater than the number recovered from patients with sarcoidosis and histiocytosis $\mathrm{X}$ (table 1 , $\mathrm{p}<0.05$ for each comparison between hypersensitivity pneumonitis and other granulomatous diseases). Similarly, the number of mast cells recovered from patients with hypersensitivity pneumonitis was significantly greater than that observed in patients with various other interstitial lung diseases (for example, $p<0.01$ when patients with fibrosing alveolitis or fibrosing alveolitis associated with connective tissue disorders were compared with patients with hypersensitivity pneumonitis - data not shown).

CHANGES IN THE NUMBER OF INFLAMMATORY CELLS RECOVERED BY LAVAGE AFTER

CESSATION OF ANTIGEN EXPOSURE

A striking feature of the alveolitis of hypersensitivity pneumonitis is the rapid change seen in the numbers and types of inflammatory cells present after cessation of antigen exposure. The number of neutrophils present in lavage fluid was quite high in patients recently exposed to antigen (fig $1 a$ ). The number of neutrophils fell rapidly when exposure to antigen was prevented ( $\mathrm{p}<0.05$, lavage 1-2 days $v 11-30$ days after exposure). Similarly, the number of eosinophils recovered by lavage appeared to fall when exposure 
Table 1 Numbers of types of cells recovered by lavage $\dagger$ from patients with hypersensitivity pneumonitis and other granulomatous lung diseases and from normal volunteers (means with standard deviations in parentheses)

\begin{tabular}{|c|c|c|c|c|c|c|}
\hline Group & Total cells & Macrophages & Lymphocytes & Neutrophils & Eosinophils & Mast cells \\
\hline $\begin{array}{l}\text { Hypersensitivity } \\
\text { pneumonitis }(n=20)\end{array}$ & & & & & & \\
\hline $\begin{array}{l}\text { Cells } \times 10^{3} / \mathrm{ml} \\
\text { Percentage }\end{array}$ & $989.6(485.3)^{* * *}$ & $\begin{array}{l}181 \cdot 6(76 \cdot 7) \\
23 \cdot 2(13 \cdot 7)^{* * *}\end{array}$ & $\begin{array}{l}703 \cdot 1(457 \cdot 9)^{* * * *} \\
65 \cdot 9(18 \cdot 1)^{* * *}\end{array}$ & $\begin{array}{l}72.8(115.8)^{*} \\
7.2(8.0)^{* *}\end{array}$ & $\begin{array}{c}15.4(13.9)^{* * *} \\
2.2(2 \cdot 5)^{* *}\end{array}$ & $\begin{array}{c}17 \cdot 6(18 \cdot 0)^{* * *} \\
1.7(1 \cdot 2)^{* * *}\end{array}$ \\
\hline $\begin{array}{l}\text { Sarcoidosis }(\mathrm{n}=92) \\
\text { Cells } \times 10^{3} / \mathrm{ml} \\
\text { Percentage }\end{array}$ & $305.5(156.9)^{* * *}$ & $\begin{array}{l}164.5(93.9) \\
56.3(16.9)^{* * *}\end{array}$ & $\begin{array}{r}132 \cdot 2(90 \cdot 4)^{* * * *} \\
41 \cdot 1(16 \cdot 9)^{* * *}\end{array}$ & $\begin{array}{l}5 \cdot 3(6 \cdot 6) \\
1 \cdot 6(1 \cdot 7)\end{array}$ & $\begin{array}{l}2.8(10 \cdot 2) \\
0.7(1.3)\end{array}$ & $\begin{array}{l}0.8(1.7) \\
0.24(0.36)^{* * *}\end{array}$ \\
\hline $\begin{array}{l}\text { Histiocytosis X }(\mathrm{n}=12) \\
\text { Cells } \times 10^{3} / \mathrm{ml} \\
\text { Percentage }\end{array}$ & $644 \cdot 3(348 \cdot 9)^{* * *}$ & $\begin{array}{l}524.0(335.7)^{* * *} \\
77.5(15.4)^{*}\end{array}$ & $\begin{array}{l}66 \cdot 1(52 \cdot 2)^{* *} \\
13 \cdot 5(9 \cdot 2)\end{array}$ & $\begin{array}{l}23 \cdot 7(27 \cdot 1)^{* *} \\
3 \cdot 8(4 \cdot 1)^{*}\end{array}$ & $\begin{array}{c}31.9(26 \cdot 1)^{* * * *} \\
6 \cdot 3(6 \cdot 0)^{* * *}\end{array}$ & $\begin{array}{l}4.0(5 \cdot 1)^{* *} \\
0.6(0 \cdot 8)^{*}\end{array}$ \\
\hline $\begin{array}{l}\text { Cells } \times 10^{3} / \mathrm{ml} \\
\text { Percentage }\end{array}$ & $157 \cdot 9(65 \cdot 3)$ & $\begin{array}{c}139.0(57.9) \\
87.9(5 \cdot 1)\end{array}$ & $\begin{array}{l}16 \cdot 6(9 \cdot 1) \\
10 \cdot 7(4 \cdot 8)\end{array}$ & $\begin{array}{l}2.0(1.9) \\
1.1(0.8)\end{array}$ & $\begin{array}{l}0.3(0.7) \\
0.3(0.5)\end{array}$ & $\begin{array}{l}0.015(0.05) \\
0.2(0.06)\end{array}$ \\
\hline
\end{tabular}

${ }^{*} \mathrm{p}<0.05 ;{ }^{* *} \mathrm{p}<0.01 ;{ }^{* * *} \mathrm{p}<0.001$ in the comparison with normal subjects.

†The mean (SD) percentage of lavage fluid recovered was: hypersensitivity pneumonitis, 54 (13); sarcoidosis, 59 (12); histiocytosis X, 45 (20); normal subberts, 60 (11): $p>0.2$ for all comparisons with patients with hypersensitivity pneumonitis.
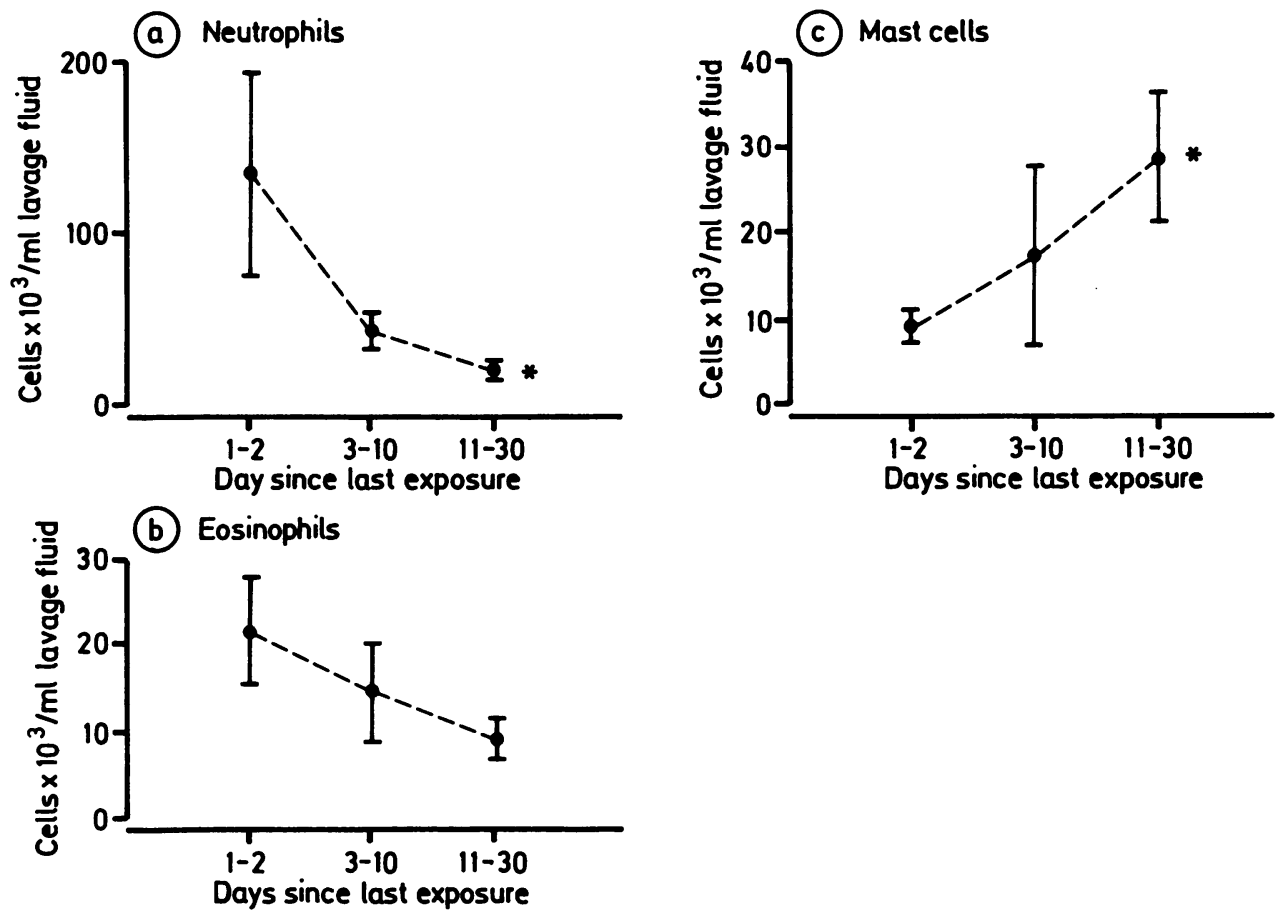

Fig 1 Changes in the numbers of inflammatory cells recovered by lavage from patients with hypersensitivity pneumonitis after discontinuation of antigen exposure. Results are shown for (a) neutrophils,

(b) eosinophils, and (c) mast cells. Patients are grouped according to the interval between last antigen exposure and lavage $(1-2 d, n=8 ; 3-10 d, n=5 ; 11-30 d, n=7)$. Results are expressed as means and standard errors. An asterisk indicates $p<0.05$ for the comparison with patients undergoing lavage 1-2 days after last antigen exposure. 
Table 2 Numbers and types of lymphocytes recovered by lavage from patients with hypersensitivity pneumonitis (means with standard deviations in parentheses)

\begin{tabular}{|c|c|c|c|c|c|c|}
\hline \multirow[b]{2}{*}{ Group } & \multirow{2}{*}{$\begin{array}{l}\text { Last antigen } \\
\text { exposure (days) }\end{array}$} & \multirow[b]{2}{*}{$n$} & \multicolumn{3}{|c|}{ No of cells $\times 10^{3} / \mathrm{ml}$ lavage fluid } & \multirow{2}{*}{$\begin{array}{l}T 4: T 8 \\
\text { ratio }\end{array}$} \\
\hline & & & Lymphocytes & $\mathrm{T4}^{+}$lymphocytes & $T 8^{+}$lymphocytes & \\
\hline $\begin{array}{l}\text { Hypersensitivity } \\
\text { pneumonitis } \\
\text { Normal }\end{array}$ & $\begin{array}{l}1-2 \\
3-10 \\
11-30 \\
\text { All patients }\end{array}$ & $\begin{array}{r}3 \\
4 \\
4 \\
11 \\
15\end{array}$ & $\begin{array}{l}425 \cdot 5(253 \cdot 1)^{* * *} \\
641.9(530 \cdot 1)^{* * *} \\
1064.2(378 \cdot 7)^{* * *} \\
703.1(457 \cdot 9)^{* * *} \\
16.6(9 \cdot 1)\end{array}$ & $\begin{array}{c}279 \cdot 2(173 \cdot 7)^{* * *} \\
299 \cdot 4(292 \cdot 0)^{* * *} \\
276 \cdot 3(131 \cdot 1)^{* * *} \\
285 \cdot 5(192 \cdot 1)^{* * *} \\
9 \cdot 5(5 \cdot 8)\end{array}$ & $\begin{array}{c}215.9(65.0)^{* * *} \\
235.5(238.8)^{* * * *} \\
815.0(181 \cdot 1)^{* * *} \\
440.9(340 \cdot 4)^{* * *} \\
5.7(3.5)\end{array}$ & $\begin{array}{l}1.3(0.9) \\
1.2(0.6) \\
0.4(0.2)^{* * *} \\
0.9(0.7)^{* *} \\
1.8(0.6)\end{array}$ \\
\hline
\end{tabular}

${ }^{*} p<0.05 ;{ }^{* *} p<0.01 ;{ }^{* * *} p<0.001$ in the comparison with normal subjects.

to antigen was prevented (fig $1 b)$, although this finding did not achieve statistical significance in this small series $(0 \cdot 05<\mathrm{p}<0 \cdot 1$, lavage $1-2$ days $v 11-30$ days after exposure).

By contrast, the number of evident mast cells recovered by lavage was relatively low in patients recently exposed to antigen, and rose progressively in patients studied at longer intervals after the last antigen exposure (fig $1 c ; \mathrm{p}<0.05$, lavage 1-2 days $v$ 11-30 days after exposure). It should be noted that

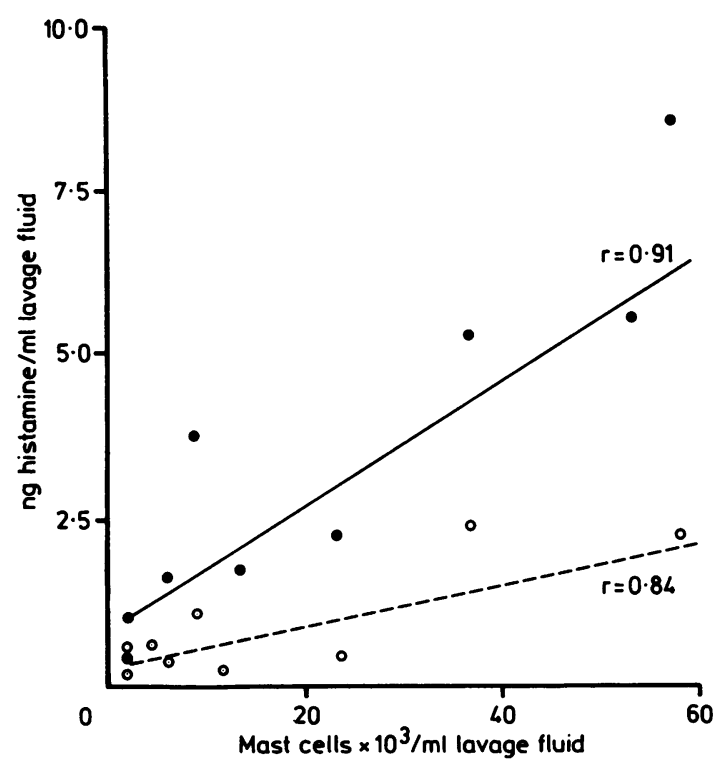

Fig 2 Relationship between the number of mast cells recovered by lavage and histamine content in lavage supernatant fluid. The number of mast cells/ml lavage fluid was determined on an aliquot of uncentrifuged lavage fluid and histamine content was determined on the supernatant of centrifuged lavage fluid. Data for histamine content in supernatant fluids separated from cells within 15 minutes of lavage (open symbols) and one hour after lavage (solid symbols) are shown. Regression lines (dashed and solid lines respectively) and corresponding $r$ values are also presented. since mast cells were identified by the presence of metachromatic cytoplasmic granules, we were unable to count mast cells which were completely degranulated or which had previously been destroyed during degranulation.

\section{CHANGES IN THE NUMBERS OF LYMPHOCYTES} RECOVERED BY LAVAGE FOLLOWING CESSATION OF ANTIGEN EXPOSURE

Cessation of antigen exposure also had an impact on the number of lymphocytes recovered by lavage from patients with hypersensitivity pneumonitis. Patients evaluated 1-2 days after antigen exposure had larger numbers of lymphocytes than those observed in normal individuals, owing to an expansion of both $\mathrm{T}^{+}$ and $\mathrm{T}^{+} \mathrm{T}$ lymphocytes (table 2 ). In patients evaluated at later times after cessation of antigen exposure a further increase in the number of lymphocytes was observed. This was almost entirely explained by an increase in the number of $\mathrm{T}^{+} \mathrm{T}$ lymphocytes; consequently, the T4:T8 ratio in patients evaluated 11-30 days after exposure was significantly lower than that observed in patients evaluated soon after antigen exposure. Although both the number of $\mathrm{T}^{+}$lymphocytes and the number of evident mast cells increased when antigen exposure was stopped, the time course for the increase in $\mathrm{T}^{+} \mathrm{T}$ lymphocytes appeared to lag behind that of mast cells (compare table 2 and fig $1 c$ ).

\section{ANALYSIS OF HISTAMINE CONTENT IN LAVAGE FLUID}

In an effort to demonstrate directly that recent exposure to antigen was associated with mast cell degranulation, we measured histamine content in the supernatant of centrifuged lavage fluid. The single most important factor determining the histamine content of such supernatants, however, was the number of evident mast cells originally present (fig 2). To evaluate whether this free histamine had been released in situ or resulted from release of histamine during lavage or subsequent handling of cells, we took advantage of the fact that, for some patients, two samples of supernatant fluid were available, one that 
had been separated from cells shortly after lavage (under 15 minutes) and a second for which the time between the completion of lavage and centrifugation of lavage fluid was considerably longer (1 hour). Consistent with the possibility that the lavage procedure or subsequent handling of lavage fluid (or both) had induced mast cell degranulation, the quantity of histamine present was considerably higher in samples where cells and liquid had remained in contact for a longer time (fig $2 ; \mathrm{p}<0.001$ by paired analysis).

\section{Discussion}

The hypothesis that antigen induced degranulation of mast cells present within the lung parenchyma has a central role in the pathogenesis of hypersensitivity pneumonitis is consistent with several important clinical and histological features of the disease. Firstly, the appearance of symptoms 4-8 hours after antigen exposure in patients with hypersensitivity pneumonitis could be readily explained by a so called "late phase reaction" or "late allergic response." Late allergic responses seen in other diseases are known to be preceded by and associated with evidence of mast cell degranulation. ${ }^{31} 32$ The absence of symptoms immediately after antigen re-exposure might indicate that only lung parenchymal mast cells, not airway mast cells, are sensitised, and that parenchymal mast cell degranulation per se is not sufficient to produce respiratory symptoms. Consistent with this idea, late allergic reactions in other systems have been shown to depend ultimately on the recruitment of inflammatory cells. ${ }^{31}$ Nevertheless, in a few patients with hypersensitivity pneumonitis immediate "asthma like" responses are also seen. ${ }^{2}$ Thus a component of mast cell mediated immediate airway hypersensitivity may occur in some individuals.

Secondly, the release of vasoactive substances, chemotactic factors, and other mediators known to be present in mast cell granules ${ }^{33}$ could account for many of the histopathological features seem in hypersensitivity pneumonitis, including interstitial and alveolar oedema and infiltration with neutrophils and eosinophils, as well as structural changes in lung parenchymal cells. ${ }^{5-7}$ For example, polymorphonuclear leucocytes are also required to produce late allergic reactions, ${ }^{3134}$ and a mast cell derived neutrophil chemotactic factor has been shown to be released in late allergic reactions. ${ }^{35}$ In addition, chronic mast cell degranulation has been suggested to play a part in fibrotic reactions, and therefore would help to explain the tendency of patients chronically exposed to antigens to develop fibrotic lesions. ${ }^{36}$

Thirdly, if chronic antigen exposure results in mast cell degranulation, this could explain why symptoms are usually more severe when antigen exposure occurs after several days of avoiding antigen. In these cases avoiding antigen would permit the reaccumulation of sensitised and fully granulated mast cells.

Finally, if the presence of appropriately sensitised mast cells is required to develop hypersensitivity pneumonitis, this would account for the fact that the presence in the lungs of antigen specific immunoglobulins and $\mathrm{T}$ lymphocytes, frequently seen in antigen exposed but symptomless individuals, ${ }^{10111421}$ is probably necessary but not sufficient to produce the disease.

The results presented here are consistent with this hypothesis. Firstly, large numbers of mast cells are present in the lower respiratory tract of patients with hypersensitivity pneumonitis. On the assumption that the number of evident mast cells observed in patients evaluated more than 10 days after antigen exposure more closely reflects the actual number of mast cells present before antigen re-exposure (see below), patients with hypersensitivity pneumonitis have over 2000 times more mast cells recovered by bronchoalveolar lavage than normal individuals. This increase in mast cells is more important than that observed for any other cell type, and the number of mast cells present in hypersensitivity pneumonitis is much larger than that observed in patients with other interstitial lung diseases, including other granulomatous lung diseases.

Secondly, the number of evident mast cells recovered by lavage from patients with hypersensitivity pneumonitis increased when antigen exposure was stopped. At any given time the number of mast cells present in the lower respiratory tract represents a balance between the loss of mast cells due to degranulation and the replenishment of the population by recruitment of new cells or regranulation. Thus the relatively small number of mast cells $\frac{\rho}{3}$ observed in patients with recent antigen exposure is consistent with the possibility that antigen exposure had induced mast cell degranulation and thereby ren- $\frac{7}{0}$ dered these cells undetectable by the methods used (for example, produced degranulated cells or resulted $\mathcal{O}$ in degranulation induced cell death). The time course $N$ for the increase in mast cells observed in our study is consistent with that of mast cell regranulation $\omega$ observed in vitro. ${ }^{3738}$ Recruitment of mast cells to the lung, mast cell proliferation, and changes in the distribution of mast cells between the interstitium and $\stackrel{D}{\Phi}$ alveolar lumen may, however, also play a part in the $?$ increase in mast cells seen after antigen exposure has ceased. Evaluation of the number of mast cells recov- $\frac{\mathbb{D}}{\mathbb{D}}$ ered by lavage before and after controlled antigen $\frac{\stackrel{\rho}{\Phi}}{\Phi}$ exposure by techniques that detect both granulated $\stackrel{\odot}{\circ}$ and degranulated mast cells will be required to establish the mechanism or mechanisms. 
Finally, important changes were observed in the numbers of other immune and inflammatory cells present in the lower respiratory tract as a function of time since antigen exposure. In each case, the time course of these changes was consistent with the possibility that they were linked to mast cell degranulation. Large numbers of neutrophils and eosinophils were present in patients recently exposed to antigen. Both neutrophil and eosinophil chemotactic factors are known to be released by mast cells. ${ }^{3335}$ Furthermore, the fall in the number of neutrophils (and possibly eosinophils) when antigen exposure was stopped occurred concomitantly with the increase in the number of evident mast cells, as would be expected if mast cell degranulation had been important in recruiting these cells to the lung. Similarly, the number of $\mathrm{T} 8^{+}$ lymphocytes increased significantly when antigen exposure was stopped, although the increase in $\mathrm{T}^{+}$ lymphocytes appeared to follow that of mast cells. In this context, $\mathrm{T}^{+}$lymphocytes have large numbers of histamine receptors, and histamine exposure can inhibit proliferation of $\mathrm{T}$ lymphocytes. ${ }^{39} 40$

Previous workers have also suggested that mast cells may have a role in the pathogenesis of hypersensitivity pneumonitis. Increased numbers of mast cells have been described in lung tissue and lavage fluid from patients with hypersensitivity pneumonitis. ${ }^{61641}$ Fournier et $l^{17}$ have suggested that release of a mast cell derived chemotactic factor might explain the influx of neutrophils seen after antigen challenge. Our findings extend these previous observations, and we suggest that the mast cell may have a central role in hypersensitivity pneumonitis.

We would emphasise that the data available at present do not firmly establish a role for mast cells in hypersensitivity pneumonitis for several reasons. Firstly, antigen induced mast cell degranulation has not been directly demonstrated. The evaluation of histamine in lavage fluid reported here showed a significant correlation between the number of mast cells present and the histamine content. Similar findings have previously been reported. ${ }^{41}$ Furthermore, the histamine content of lavage supernatant increased if separation of cells and supernatant was delayed. These results strongly suggest that the histamine present results from degranulation of mast cells initiated by the lavage procedure itself or subsequent handling of lavage fluid, and did not reflect free histamine present in vivo. Since patients with small numbers of evident mast cells (that is, patients recently exposed to antigen) had relatively low concentrations of histamine, this indicates that histamine did not accumulate to any great extent in the lower respiratory tract of patients recently exposed to antigen. This interpretation is consistent with the knowledge that histamine, like many mast cell derive mediators, has a short half life in vivo, ${ }^{32} 33$ and suggests that the direct demonstration of antigen induced mast cell degranulation may be difficult in patients chronically exposed to antigens. Furthermore, our results indicate that morphological or biochemical evidence for degranulation of mast cells obtained by lavage must be viewed with scepticism unless artefacts resulting from the lavage procedure are excluded.

Even if antigen induced mast cell degranulation can be demonstrated in hypersensitivity pneumonitis, additional studies will be required to define the role of mast cells in the disease. It will be important to understand the mechanism or mechanisms accounting for mast cell accumulation and sensitisation and determine the role, if any, of mast cell mediators in producing the clinicopathological changes seen in hypersensitivity pneumonitis. Finally, the hypothesis that mast cells have a central role in the pathogenesis of hypersensitivity pneumonitis would suggest that increased numbers of appropriately sensitised mast cells would not be present in symptomless individuals exposed to antigen. Information on this point is currently not available. Nevertheless, whether or not future studies confirm the central role of lung mast cells proposed here, further evaluation of the role of mast cells in hypersensitivity pneumonitis may be a fruitful endeavour in better defining the pathogenesis and treatment of this disorder.

\section{References}

1 Pepys J. Hypersensitivity disease of the lungs due to fungi and other organic dusts. Monogr Allergy 1969;4:44-147.

2 Fink JN. Hypersensitivity pneumonitis. J Allergy Clin Immunol 1984;74:1-9.

3 Larsen GL. Hypersensitivity lung disease. Ann Rev Immunol 1985;3:59-85.

4 Fink JN. Clinical features of hypersensitivity pneumonitis. Chest 1986;89:193-5S.

5 Reyes CN, Wenzel FJ, Lawton BR, Emanuel DA. The pulmonary pathology of farmer's lung disease. Chest 1982;81:142-6.

6 Kawanami O, Basset F, Barrios R, Lacronique JG, Ferrans VJ, Crystal RG. Hypersensitivity pneumonitis in man. Light- and electron-microscopic studies of 18 lung biopsies. Am J Pathol 1983;110:277-91.

7 Basset F, Ferrans VJ, Soler P, Takemura T, Fukuda Y, Crystal RG. Intraluminal fibrosis in interstitial lung disorders. Am J Pathol 1986;122:443-61.

8 Fink JN, Moore VL, Barboriak JJ. Cell-mediated hypersensitivity in pigeon breeders. Int Arch Allergy Appl Immunol 1975;49:831-6.

9 Reynolds HY, Fulmer JD, Kazmierowski JA, Roberts WC, Frank MM, Crystal RG. Analysis of cellular and protein content of broncho-alveolar lavage fluid from patients with idiopathic pulmonary fibrosis and chronic hypersensitivity pneumonitis. $J$ Clin Invest 1977;59:165-75. 
10 Leatherman JW, Michael AF, Schwartz BA, Hoidal JR. Lung $\mathrm{T}$ cells in hypersensitivity pneumonitis. Ann Intern Med 1984;100:390-2.

11 Cormier Y, Bélanger J, Beaudoin J, Laviolette M, Beaudoin R, Hebert J. Abnormal bronchoalveolar lavage in asymptomatic dairy farmers. Study of lymphocytes. Am Rev Respir Dis 1984;130:1046-9.

12 Costabel U, Bross KJ, Marxen J, Matthys H. Tlymphocytosis in bronchoalveolar lavage fluid of hypersensitivity pneumonitis. Changes in profile of Tcell subsets during the course of disease. Chest 1984;85:514-8.

13 Mornex JF, Cordier G, Pages J, et al. Activated lung lymphocytes in hypersensitivity pneumonitis. J Allergy Clin Immunol 1984;74:719-27.

14 Keller RH, Swartz S, Schlueter DP, Bar-Sela S, Fink JN. Immunoregulation in hypersensitivity pneumonitis: phenotypic and functional studies of bronchoalveolar lavage lymphocytes. Am Rev Respir Dis 1984;130: 766-71.

15 Semenzato G, Chilosi M, Ossi E, Zambello R, Marcer G, Gasparatto G. Bronchoalveolar lavage and lung histology. Comparative analysis of inflammatory and immunocompetent cells in patients with sarcoidosis and hypersensitivity pneumonitis. Am Rev Respir Dis 1985;132:400-4.

16 Haslam PL, Dewar A, Butchers P, Turner-Warwick M. Mast cells in bronchoalveolar lavage fluids from patients with extrinsic allergic alveolitis (synonym: hypersensitivity pneumonitis) [abstract]. Am Rev Respir Dis 1982;125:51A.

17 Fournier E, Tonnel AB, Gosset P, Wallaert B, Ameisen JC, Voisin C. Early neutrophil alveolitis after antigen inhalation in hypersensitivity pneumonitis. Chest 1985;88:563-6.

18 Voisin C, Tonnel AB, Lahoutec C, Robin H, Lebas J, Aerts C. Bird fancier's lung: studies of bronchoalveolar lavage and correlations with inhalation provocation tests. Lung 1981;159:17-22.

19 Daniele RP, Henson PM, Fantone JC III, Ward PA, Dreisin RB. Immune complex injury of the lung. Am Rev Respir Dis 1981;124:738-55.

20 Salvaggio JE, de Shazo RD. Pathogenesis of hypersensitivity pneumonitis. Chest 1986;89:190S-3S.

21 Moore VL, Pederson GM, Hauser WC, Fink JN. A study of lung lavage materials in patients with hypersensitivity pneumonitis: in vitro response to mitogen and antigen in pigeon breeders disease. J Allergy Clin Immunol 1980;53:319-28.

22 Wenzel FJ, Emanuel DA, Gray RL. Immunofluorescent studies in patients with farmer's lung. $J$ Allergy Clin Immunol 1971;48:224-9.

23 Ghose T, Landrigan P, Killeen R, Dill J. Immunopathological studies in patients with farmer's lung. Clin Allergy 1974;4:119-29.

24 Moore VL, Fink JN, Barboriak JJ, Ruff LL, Schlueter DP. Immunologic events in pigeon breeder's disease. $J$ Allergy Clin Immunol 1974;53:319-28.

25 Baur X, Dorsch W, Becker T. Levels of complement factors in human serum during immediate and late asth- matic reactions and during acute hypersensitivity pneumonitis. Allergy 1980;35:383-90.

26 Georges R, Saumon G, Loiseau A. The relationship of age to pulmonary membrane conductance and capillary blood volume. Am Rev Respir Dis 1978;117 1069-78.

27 Quanjer PH, ed. Standardized lung function testing. European Community for coal and steel. Bull Eur Physiopathol Respir 1983;19(suppl 5):45-51.

28 Hance AJ, Basset F, Saumon G, et al. Smoking and interstitial lung disease. The effect of cigarette smoking on the incidence of pulmonary histiocytosis $\mathrm{X}$ and sarcoidosis. Ann NY Acad Sci 1986;465:641-56.

29 Chollet S, Soler P, Dournovo P, Richard MS, Ferrans VJ, Basset F. Diagnosis of pulmonary histiocytosis X by immunodetection of Langerhans cells in bronchoalveolar lavage fluid. Am J Pathol 1984;115:225-32.

30 Lebel B. A high sampling-rate automated continuousflow fluorometric technique for the analysis of nanogram levels of histamin in biological samples. Analy Biochem 1983;133:16-29.

31 Kaliner $\mathbf{M}$, Lemanske $\mathbf{R}$. Inflammatory responses to mast cell granules. Fed Proc 1984;43:2846-51.

32 Naclerio RM, Proud D, Togias AG, et al. Inflammatory mediators in late antigen-induced rhinitis. $N$ Engl $J$ Med 1985;313:65-70.

33 Schwartz LB, Austen KF. Structure and function of the chemical mediators of mast cells. Prog Allergy 1984;34:271-321.

34 Murphy KR, Wilson MC, Irvin CG, et al. The requirement for polymorphonuclear leukocytes in the late asthmatic response and heightened airways reactivity in an animal model. Am Rev Respir Dis 1986;134:62-8.

35 Nagy L, Lee TH, Kay AB. Neutrophil chemotactic activity in antigen-induced late asthmatic reactions. $N$ Engl J Med 1982;306:497-501.

36 Claman HN. Mast-cells, T cells and abnormal fibrosis Immunol Today 1985;6:192-5.

37 Dvorak AM, Galli SJ, Morgan E, Galli AS, Hammond E, Dvorak HF. Anaphylactic degranulation of guinea pig basophilic leukocytes. II. Evidence for regranulation of mature basophils during recovery from degranulation in vitro. Lab Invest 1982;46:461-75.

38 Weill BJ, Renoux ML. Study of granule reappearance and histamine synthesis in rat mast cells maintained in short term cultures. Cell Immunol 1982;68:220-33.

39 Sansoni P, Silverman ED, Khan MM, Melmon KL, Engleman EG. Immunoregulatory $\mathrm{T}$ cells in man Histamine-induced suppressor $T$ cells are derived from Leu $2^{+}\left(\mathrm{T}^{+}\right)$subpopulation distinct from that which gives rise to cytotoxic $\mathrm{T}$ cells. $J$ Clin Invest 1985;75:650-6.

40 Khan MM, Sansoni P, Engleman EG, Melmon KL. Pharmacologic effects of autacoids on subsets of $T$ cells. Regulation of expression/function of histamine-2 receptors by a subset of suppressor cells. $J$ Clin Invest 1985;75:1578-83.

41 Agius RM, Godfrey RC, Holgate ST. Mast cell histamine content of human bronchoalveolar lavage fluid. Thorax 1985;40:760-7. 